\title{
Determinants of dividend policy in Palestinian banks
}

\author{
Yarob Kullab $^{a^{*}}$, Nabil Messabia ${ }^{b}$, Issam Altaweel ${ }^{a}$ and Mohammed Shehada ${ }^{a}$
}

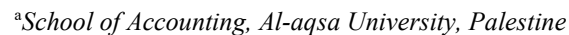

${ }^{b}$ Department of Accounting Sciences, Université du Québec en Outaouais, Canada

\section{H R O N I C L E}

\begin{tabular}{l}
\hline Article history: \\
Received August 1, 2021 \\
Received in revised format \\
September 222021 \\
Accepted September 302021 \\
Available online \\
September 302021 \\
\hline Keywords: \\
Dividend policy \\
Agency cost theory \\
Signaling theory \\
Regulatory hypothesis \\
Palestine \\
Banks
\end{tabular}

\section{Introduction}

The dividend policy is among the most important strategic decisions taken by banks worldwide. Nevertheless, despite Miller and Modigliani (1961)'s landmark research and many subsequent studies there is still a lack of consensus on the determinants of dividend policy, hence the so-called dividend puzzle remains unsolved (Séverin \& du Jardin, 2011). The crux of this puzzle can be summarized as follows: some well-performing companies do not pay dividends while other poorly-performing companies do pay dividends. In their work, Miller and Modigliani (1961) propose the irrelevance theory of dividends, which they built based on the assumption of a perfect capital market and the presence of information symmetry. Accordingly, the authors argue that any adopted dividend policy will not affect a company's current market value. However, many other studies have criticized this argument because they contend that, in the real world, markets are imperfect and information asymmetry is present. Within the market imperfections framework, other studies have used a variety of different theories to explain dividend policy determinants. For instance, according to dividend-preference theory or bird-in-hand theory, a dividend policy affects a company's market value (Gordon, 1963; Lintner, 1964). As specified in dividend-signaling theory, the dividend policy of a company conveys information about the company's well-being to

* Corresponding author.

E-mail address: yj.kolab@alaqsa.edu.ps (Y. Kullab)

C 2022 Growing Science Ltd. All rights reserved. doi: 10.5267/j.ac.2021.9.002 
shareholders, e.g., its profitability, so an increase in the dividend payout is interpreted as a positive signal, whereas a decrease is interpreted as a negative signal (Bhattacharya, 1979; Kalay, 1980; John \& Williams, 1983). Meanwhile, the agency cost assumption in free cash flow theory posits that when managers have more cash than needed to fund new positive net present value projects, this creates an incentive for managers to waste the free cash on unprofitable investments such as acquisitions rather than pay it back to shareholders in the form of dividends (Jensen, 1986). In a similar vein, according to pecking order theory, companies prefer to use retained earnings to fund prospective investment opportunities and to adapt their dividend policies accordingly, whereby the ranking of internal equity, i.e., retained earnings would be placed at the top of the pecking order, followed by debt and then external equity at the bottom of the pecking order (Myers, 1984; Myers \& Majiuf, 1984; Strong, 1998). Lastly, in catering theory it is postulated that managers will be willing to pay dividends only if the positive premium on the stock price that would result from these dividends is higher than the long-term costs of paying these dividends (Baker \& Wurgler, 2004a, 2004b). Importantly, the aforementioned dividend theories were initially developed for and applied to non-financial companies in developed economies (Budagaga, 2020), therefore most of the empirical evidence is based on this context. Therefore, the present study tries to fill this gap by focusing on the financial sector and an emerging economy, specifically the banking sector in Palestine. Furthermore, prior studies have provided inconclusive findings. Hence it has been suggested that future studies should use companies' propensity to pay dividends as well as companies' dividend payout ratios concurrently when seeking to identify dividend policy determinants in order to make a significant contribution in terms of finding a solution to the dividend determinant puzzle (Dewasiri et al., 2019), i.e., why some organizations pay dividends and others do not. In line with this suggestion, the present study uses banks' propensity to pay dividends and banks' dividend payout ratios concurrently when analyzing the dividend determinants of Palestinian banks. Specifically, this study aims to (i) examine whether the dividend theories that were principally developed for non-financial companies in developed institutional environments and extensively examined in such environments can explicate the dividend policies of banks in Palestine, which is characterized as an emerging market with a high level of uncertainty or a "disturbed environment" and (ii) determine the main factors affecting Palestinian banks" propensity to pay dividends and the banks' dividend payout ratios.

\section{Palestine Institutional Background}

Palestine - a disturbed environment - has witnessed continuous conflicts due to the Israeli occupation. In fact, Israel controls the airspace, ports and border crossings of Palestine and thus controls the movement of people, goods and money. Furthermore, Israel has imposed a strict siege since 2007 as well as launched three wars on Palestine in 2009,2012 and 2014. Accordingly, the aforementioned events have adversely affected the political, social and economic conditions of the Palestinian economy and thus the Palestinian banking sector (Kullab \& Yan, 2018). Given the above, the banking sector in Palestine is considered the major engine of the Palestinian economy, and thus leads any improvements in respect of the productive capacity of the national economy (Abusharbeh, 2020). Therefore, the present study aims to examine the Palestinian banking sector determinants that affected dividend policy during the period 2010-2019. Moreover, emerging markets in the Middle East and North Africa region are scarcely explored in terms of dividend policy determinants (Chowdhury et al., 2014; Budagaga, 2020), as is the case with Palestine where no studies have documented dividend policy determinants.

\section{Literature Review and Hypotheses Development}

\subsection{Size}

A company's size has become a key variable in explaining its dividend payment decisions (Budagaga, 2020). According to agency cost theory, managers of large-size organizations that have widespread ownership are controlled by agents (management) who have a tendency to pay dividends to shareholders in order to mitigate agency costs (Jensen \& Meckling, 1976). Also, Aivazian and Booth (2003) argue that larger companies, which have better access to markets, are able to pay higher dividends. Furthermore, Fama and French (2001) found that in the United States dividend payers are much larger than non-payers Consistently, studies such as Warganegara et al. (2020), Budagaga (2020), Dewasiri et al. (2019), and Boţoc and Pirtea (2014) find that the company size positively affects the company dividend policy. Accordingly, it is expected that the bank's size will have a positive influence on its dividend policy, and for the purposes of the present study this hypothesis is formulated as follows:

H1a: Ceteris paribus, the larger the bank is, the more likely it is to pay dividends.

H1b: Ceteris paribus, the larger the bank is, the more likely it is to raise its dividend payout ratio.

\subsection{Profitability}

Dividend-signaling theory (Bhattacharya, 1979; Kalay, 1980; John \& Williams, 1983) suggests that companies with stable profitability have a greater tendency to pay dividends and/or to raise their dividend payout ratios in order to signal their expected performance to the market. Thus, it follows that companies confronting bad economic conditions naturally would not have the ability to pay dividends. Furthermore, Kauko (2012) argues that banks might pay dividends, as a source of 
information for uninsured depositors, signaling their profitability. Also, Budagaga (2020) argues that usually companies make dividend decisions based on their profitability. Hence, it is anticipated that profitable companies will have a better capability to pay and/or raise dividends. In the same line, Budagaga (2020), Dewasiri et al. (2019), Boţoc and Pirtea (2014) and Fama and French (2001) find that an organization's profitability has a positive impact on its dividend policy. Accordingly, it is expected that the bank's profitability level will have a positive influence on its dividend policy, and therefore for the present study the following hypothesis is developed:

H2a: Ceteris paribus, the higher the bank's profitability, the more likely it is to pay dividends.

H2b: Ceteris paribus, the higher the bank's profitability, the more likely it is to raise its dividend payout ratio.

\subsection{Liquidity}

According to dividend-signaling theory, banks use dividends as an important source of information to signal their soundness in terms of liquidity (Calomiris \& Nissim, 2014; Forti \& Schiozer, 2015). Therefore, company liquidity (cash) is among the vital factors that affect dividend payment decisions; when companies have adequate levels of cash they will not face difficulties in paying cash dividends. Baker et al. (2008), Boţoc and Pirtea (2014) and Budagaga (2020) further argue that regardless of the level of a company's profitability, it is its cash level that acts a crucial determinant in its decision to pay cash dividends. Consistent results in this regard have been reported by prior studies (Ho, 2003; Kuo et al., 2013; Kumar \& Waheed, 2015). Accordingly, it is expected that the bank's liquidity (cash level) will have a positive influence on its dividend policy, thus the following hypothesis is constructed:

H3a: Ceteris paribus, the higher the bank's liquidity level, the more likely it is to pay dividends.

H3b: Ceteris paribus, the higher the bank's liquidity level, the more likely it is to raise its dividend payout ratio.

\subsection{Capital adequacy}

Unlike most dividend policy studies which have been conducted on non-financial companies, the present study concentrates on financial companies, i.e., banks. The nature of banks' activities differs from those of other types of companies. Furthermore, their capital structure is quite different from that of non-bank companies because the former consists of deposits that are considered as a substantial financing tool in the banking sector (Baker et al., 2008; Gropp \& Heider, 2010; Kauko, 2012; Budagaga, 2020). Thus, the present study considers bank capital adequacy as a bank nature-related determinant of banks' dividend policy decisions. During the last decade, the focus on regulating banks' dividend policies has increased because some banks distributed large dividend payouts during the 2007-2008 financial crises (Acharya et al., 2011). As a consequence, banks became highly regulated both nationally and internationally in order to deter any prospect of opportunistic behavior that might lead to failure. Furthermore, Baker et al. (2008) note that generally the banking sector has strict regulations in place in respect of non-performing loan ratios, liquidity ratios and capital adequacy ratios. Hence Lepetit et al. (2018) and Budagaga (2020) further argue that banks' dividend policies are subject to regulatory pressures known as the regulatory hypothesis. This hypothesis posits that regulatory pressures restrict a bank's dividend payments according to some determinants such as the capital adequacy level (leverage level); so when the bank has a high capital adequacy level (low leverage level) it has a greater ability to pay dividends. Gropp and Heider (2010), Abreu and Gulamhussen (2013) Lepetit et al. (2018) and Budagaga (2020) report consistent results that support the regulatory hypothesis scenario. Accordingly, it is expected that the bank's capital adequacy level will have a positive influence on its dividend policy, as formulated in the following hypothesis:

H4a: Ceteris paribus, the higher the bank's capital adequacy level, the more likely it is to pay dividends. H4b: Ceteris paribus, the higher the bank's capital adequacy level, the more likely it is to raise its dividend payout ratio.

\section{Methodology}

\subsection{Data sample}

The data for this study were collected from banks' annual reports. The data covers the period from 2010 through 2019 (10 years). All Palestinian listed banks are included in the study. As there are six listed banks in Palestine, this yields a final sample of 60 bank-year observations. The name and the number of branches of each bank are provided in Table 1 .

\section{Table 1}

Listed Banks in Palestine

\begin{tabular}{ll}
\hline Bank Name & No. of Branches \\
\hline Bank of Palestine & 57 \\
Quds Bank & 31 \\
Palestine Investment Bank & 15 \\
The National Bank & 11 \\
Arab Islamic Bank & 11 \\
Palestine Islamic Bank & 23 \\
\hline Sour
\end{tabular}




\subsection{Definition of the variables}

4.2.1 Dependent variables: Two dependent variables are used. The first dependent variable is the most-used dependent variable in the related literature, namely, the propensity to pay dividends. It depicts the bank's decision to pay or not pay dividends, regardless of how much dividends are paid. It is represented by a dummy variable (DIV_D), where it takes the value of 1 if a bank pays dividends, and zero otherwise (Budagaga, 2020; Rodrigues et al., 2020; Dewasiri et al., 2019; Ashraf \& Zheng, 2015; Forti \& Schiozer, 2015; Kuo et al., 2013; Al-Malkawi, 2008; Fama $\&$ French, 2001). The second dependent variable is a widely used dependent variable in the literature, namely, the dividend payout ratio or the amount of paid dividends (DPOR). It is measured as the paid dividends to total assets ratio (Lepetit et al., 2018; Ashraf \& Zheng, 2015; Boţoc \& Pirtea, 2014; Abreu \& Gulamhussen, 2013; Aivazian \& Booth, 2003).

4.2.2 Independent variables: Four independent variables are considered. Bank size (LOG TA), which is measured as the natural logarithm of total assets (Budagaga, 2020; Ashraf \& Zheng, 2015). Bank profitability (ROAA), which is defined as the return on average assets (Lepetit et al., 2018; Forti \& Schiozer, 2015). Bank liquidity (CASH_R), which is calculated as cash and cash equivalent balances divided by total assets (Al-Kayed, 2017; Kumar \& Waheed, 2015). The fourth is bank capital adequacy (E_TA), which is measured as the equity divided by the total assets (Budagaga, 2020; Lepetit et al., 2018). Note that all the independent variables are lagged by one year in order to control for the endogeneity issue, which is an approach that is consistent with the literature (Budagaga, 2020; Forti \& Schiozer, 2015; Yoshikawa \& Rasheed, 2010).

4.2.3 Control variables: Three dummy variables are employed. A year dummy variable (YEAR) is used to control the unobserved effect of time variations, e.g., variation in bank regulations on dividend payments (Budagaga, 2020; Lepetit et al., 2018). A war time dummy variable (WAR) because this study covers the period from 2010 to 2019 , during which the Israeli government launched two wars against the Palestinian people in 2012 and 2014 which inevitably affected business activities and the data for those years (Kullab \& Yan, 2018; Barhamzaid et al., 2018). The third is a bank type dummy variable (BANK_D) because the data sample includes conventional and Islamic banks (Kullab \& Yan, 2018; Al-Kayed, 2017). Table 2 presents the definitions of the variables used in the study.

Table 2

Definitions of the Study Variables.

\begin{tabular}{lll}
\hline Variables & Symbol & Definitions \\
\hline $\begin{array}{l}\text { Dependent variables } \\
\text { Propensity to pay dividends }\end{array}$ & DIV_D & Takes the value of 1 if bank $i$ pays a dividend, and zero otherwise at year $t$ \\
\hline $\begin{array}{l}\text { Independent variables } \\
\text { Size }\end{array}$ & DPOR & Ratio of dividends paid to total assets of bank $i$ at year $t$ \\
$\begin{array}{l}\text { Profitability } \\
\text { Liquidity }\end{array}$ & LOG_TA & Natural logarithm of the total assets of bank $i$ at year $t$ \\
$\begin{array}{l}\text { Capital adequacy } \\
\text { Control variables }\end{array}$ & Rash_R & Ratio of net income to average total assets of bank $i$ at year $t$ \\
Wartime & E_TA & Ratio of equity to total assets of bank $i$ at year $t$ \\
Bank type & WAR & $\begin{array}{l}\text { Dummy variable; takes the value } 1 \text { if within a particular year a war has happened, and } \\
\text { zero otherwise } \\
\text { Dummy variable; takes the value of one if a particular bank is a conventional bank, and } \\
\text { zero otherwise }\end{array}$ \\
\hline
\end{tabular}

\subsection{Research models}

Two research models are developed in this study. In Model 1, the first dependent variable, namely, the propensity to pay dividends, is a dummy variable. Therefore, the Probit technique is appropriate to use to run this model (Gujarati, 2009):

Model 1: Probit $\left(D_{I}{ }_{-} D_{i, t}\right)=$

$$
\beta_{0}+\beta_{1} L O G_{-} T A_{i, t-1}+\beta_{2} R O A A_{i, t-1}+\beta_{3} C A S H_{-} R_{i, t-1}+\beta_{4} E_{-} T A_{i, t-1}+\beta_{5} W A R_{i, t}+\beta_{6} B A N K_{-} D_{i, t}+\beta_{7} Y E A R_{t}+\varepsilon_{i, t}
$$

Model 1 is used to test the following hypotheses: $\mathrm{Hla}, \mathrm{H} 2 \mathrm{a}, \mathrm{H} 3 \mathrm{a}$ and $\mathrm{H} 4 \mathrm{a}$.

In Model 2, the second dependent variable, namely, dividend payout ratio, is a continuous variable. Therefore, the ordinary least squares (OLS) technique is appropriate to use to run this model (Gujarati, 2009):

Model 2: $O L S\left(D P O R_{i, t}\right)=$

$\beta_{0}+\beta_{1} L O G_{-} T A_{i, t-1}+\beta_{2} R O A A_{i, t-1}+\beta_{3} C A S H_{-} R_{i, t-1}+\beta_{4} E_{-} T A_{i, t-1}+\beta_{5} W A R_{i, t}+\beta_{6} B A N K_{-} D_{i, t}+\beta_{7} Y E A R_{t}+\varepsilon_{i, t}$ 
Model 2 is used to test the following hypotheses: $H 1 b, H 2 b, H 3 b$ and $H 4 b$.

\subsection{Descriptive statistics}

Table 3 provides the frequency of Palestinian banks' propensity to pay dividends, i.e., the first dependent variable. As shown in Table 3, the number of bank-year observations in which the banks paid dividends (regardless of the amount) is 28 observations, which is equal to almost $47 \%$ of the total number of sample observations. The remaining $53 \%$ of the observations relate to non-paying banks.

Table 3

Frequency of Palestinian Listed Banks' Propensity to Pay Dividends.

\begin{tabular}{llll}
\hline Dividend Policy (DIV_D) & Freq. & Percent & Cum. \\
\hline $\mathbf{0}$ & 32 & 53.33 & 53.33 \\
\hline Total observations & 28 & 46.67 & 100 \\
\hline
\end{tabular}

Note: $0=$ non-payers. $1=$ dividend payers.

Table 4 provides summary statistics for the second dependent variable as well as the independent variables. As can be seen from Table 4, the mean value of the DPOR statistic equals 0.0022. This means that Palestinian banks, on average, paid $0.0022 \%$ of their assets as dividends. Also, the mean value of the CASH_R statistic approximately equals $21 \%$. This means that the banks, on average, maintain $21 \%$ of their assets as cash and cash equivalents. In other words, Palestinian banks keep a reasonable amount of cash and cash equivalents to meet their obligations on time. Moreover, the minimum level of the E_TA statistic. i.e., the capital adequacy level is $8 \%$. This statstic shows that Palestinian banks complied with the Basel Committee's recommendations during the period 2010-2019. Also, the mean value of the E_TA statistic is approximately $32 \%$. This shows that Palestinian banks, on average, enjoyed high levels of capital adequacy for the period 2010-2019.

Table 4

Descriptive Statistics

\begin{tabular}{lllll}
\hline Variable & Mean & Std. Dev. & Maximum & Minimum \\
\hline DPOR & 0.0022 & 0.0028 & 0.014 & 0 \\
LOG_TA & 8.8796 & 0.3619 & 9.721 & 8.199 \\
TA (000) & 1108008 & 1161984 & 5264945 & 158140 \\
ROAA & 0.0093 & 0.0048 & 0.021 & -0.008 \\
CASH_R & 0.2084 & 0.0737 & 0.5 & 0.094 \\
E_TA & 0.3221 & 0.2603 & 0.911 & 0.081 \\
\hline
\end{tabular}

\subsection{Correlation matrix and variance inflation factor (VIF)}

Table 5 reports the correlation analysis of the independent variables. The table shows that the highest correlation occurs between bank size and bank profitability with a correlation statistic of 0.524 . This statistic is under the threshold level of 0.8. Also, the variance inflation factor statistic (VIF) for every variable is less than the rule of thumb of 10, which lessens multicollinearity concerns (Gujarati, 2009).

Table 5

Correlation Matrix and Variance Inflation Factor (VIF) Values.

\begin{tabular}{llllll} 
& LOG_TA & ROAA & CASH R & E TA & VIF \\
\hline LOG_TA & 1 & & & & 1.47 \\
ROAA & $0.524 * *$ & 1 & & & 1.39 \\
CASH_R & -0.234 & -0.186 & 1 & 1 & 1.07 \\
E TA & -0.21 & -0.063 & 0.09 & 1.05
\end{tabular}

Notes: ***, **, * significant at the $1 \%, 5 \%$, and $10 \%$, respectively

\section{Results and Discussion}

The study used the pooled Probit technique to run the first regression model wherein the dependent variable was a dummy variable (DIV_D) representing Palestinian banks' propensity to pay dividends. In addition, the pooled OLS technique was used to run the second regression model wherein the dependent variable was a continuous variable (DPOR) representing the banks' dividend payout ratio. Table 6 presents the findings of the Probit and OLS analyses of the dividend policy determinants of Palestinian banks during the period 2010-2019. In Table 6, column 1 presents the results of the Probit analysis of Model 1, which was used to test hypotheses $H 1 a$, H2a, H3a and H4a. Column 2 presents the results of the OLS analysis of Model 2, which used to test hypotheses $H 1 b, H 2 b, H 3 b$ and $H 4 b$. Furthermore, for robustness purposes, all the 
continuous variables were winsorized at $2.5 \%$ and $97.5 \%$ levels in order to eliminate outlier effects, and thereafter the same analyses were performed again. Accordingly, column 3 presents the results of the Probit analysis of Model 1 and column 4 presents the results of the OLS analysis of Model 2 after the respective variables had been winsorized. Lastly, a general dominance analysis was conducted in order to determine the relative importance of the predictors.

Table 6

Findings of the Probit and OLS Analyses on the Dividend Policy Determinants in Palestinian Banks 2010-2019

\begin{tabular}{|c|c|c|c|c|c|}
\hline & \multirow{3}{*}{$\begin{array}{l}\text { Pre. } \\
\text { Sign }\end{array}$} & \multicolumn{2}{|c|}{$\begin{array}{l}\text { Pool-based Techniques } \\
\text { Main Analysis }\end{array}$} & \multicolumn{2}{|c|}{$\begin{array}{l}\text { Pool-based Techniques } \\
\text { Winsorized Data }\end{array}$} \\
\hline & & Column 1 & Column 2 & Column 3 & Column 4 \\
\hline & & $\begin{array}{l}\text { Probit } \\
\text { Analysis }\end{array}$ & $\begin{array}{l}\text { OLS } \\
\text { Analysis }\end{array}$ & $\begin{array}{l}\text { Probit } \\
\text { Analysis }\end{array}$ & $\begin{array}{l}\text { OLS } \\
\text { Analysis }\end{array}$ \\
\hline \multirow[b]{2}{*}{ IV } & & \multicolumn{4}{|c|}{ DV } \\
\hline & & DIV_D Dummy DV & DPOR Continuous DV & $\begin{array}{l}\text { DIV_D } \\
\text { Dummy DV }\end{array}$ & $\begin{array}{l}\text { DPOR } \\
\text { Continuous DV }\end{array}$ \\
\hline LOG_TA & + & $\begin{array}{l}33.27 * * * \\
(2.85)\end{array}$ & $\begin{array}{l}0.002^{* *} \\
(2.27)\end{array}$ & $\begin{array}{l}33.52^{* * *} \\
(2.87)\end{array}$ & $\begin{array}{l}0.002^{*} \\
(1.95)\end{array}$ \\
\hline ROAA & + & $\begin{array}{l}78.56^{*} \\
(1.31)\end{array}$ & $\begin{array}{l}0.164 * * \\
(2.15)\end{array}$ & $\begin{array}{l}79.21^{*} \\
(1.31)\end{array}$ & $\begin{array}{l}0.173^{* *} \\
(2.20)\end{array}$ \\
\hline CASH_R & + & $\begin{array}{l}6.29 \\
(0.93)\end{array}$ & $\begin{array}{l}0.002 \\
(1.41)\end{array}$ & $\begin{array}{l}6.70 \\
(0.97)\end{array}$ & $\begin{array}{l}0.002 \\
(1.40)\end{array}$ \\
\hline E_TA & + & $\begin{array}{l}85.86 * * * \\
(2.90)\end{array}$ & $\begin{array}{r}0.003^{*} \\
(1.87)\end{array}$ & $\begin{array}{l}86.24 * * * \\
(2.93)\end{array}$ & $\begin{array}{l}0.002 \\
(1.33)\end{array}$ \\
\hline WAR & /I & YES & YES & YES & YES \\
\hline BANK_D & // & YES & YES & YES & YES \\
\hline YEAR ${ }^{-}$ & /I & YES & YES & YES & YES \\
\hline Pseudo-R $^{2}$ & & 0.64 & -- & 0.64 & -- \\
\hline $\mathbf{R}^{2}$ & & -- & 0.54 & -- & 0.53 \\
\hline Wald $\mathrm{Chi}^{2}$ & & 338.20 & -- & 318.63 & -- \\
\hline F-test & & -- & 19.18 & -- & 17.16 \\
\hline P-value & & 0.000 & 0.000 & 0.000 & 0.000 \\
\hline $\mathbf{N}$ & & 60 & 60 & 60 & 60 \\
\hline
\end{tabular}

Notes: DV: dependent variable; IV: independent variable. Z-statistics for Probit and T-statistics for OLS are in parentheses. *, ** and *** denote 10, 5 and 1 percent significance levels, respectively (one-tailed).

As shown in Table 6, all of the models are statistically significant at the $1 \%$ level or better, as indicated by the Wald Chi ${ }^{2}$ test and F-test values. Moreover, the values of the $t$ and $z$-statistics are based on standard errors adjusted for clustering at the bank level in order to control for autocorrelation and heteroskedasticity issues (Petersen, 2009).

As regards the four potential explanatory factors, bank size (LOG_TA) significantly and positively affects Palestinian banks' propensity to pay dividends $(H I a)$ at the $1 \%$ level (column $\overline{1}$ ) and significantly and positively affects the banks' dividend payout ratio $(H 1 b)$ at the $5 \%$ level (column 2) as expected. Consequently, Hla and Hlb are supported. These results suggest that large banks are more likely to make the decision to pay cash dividends and/or to raise their cash dividend payout ratio. These results are in line with agency cost theory (Jensen \& Meckling, 1976) that implies managers of large companies have a tendency to pay dividends and/or to raise dividend payout ratios in order to mitigate agency costs. Moreover, these results are consistent with the findings of Budagaga (2020), Ashraf and Zheng (2015), Al-Najjar (2009) and Al-Malkawi (2007).

The findings of the present study also show that bank profitability (ROAA) significantly and positively affects the banks' propensity to pay dividends $(H 2 a)$ at the $10 \%$ level (column 1$)$ and significantly and positively affects the banks' dividend payout ratio $(H 2 b)$ at the $5 \%$ level (column 2 ) as expected. Consequently, $H 2 a$ and $H 2 b$ are supported. These results suggest that profitable banks are more likely to decide to disburse cash dividends and/or to increase their cash dividend payout ratio. These results are in line with dividend-signaling theory (Bhattacharya, 1979; Kalay, 1980; John \& Williams, 1983) that posits that companies with stable profitability are more likely to pay dividends and/or to raise their paid dividend ratios in order to signal to the market that they will have a promising future financial performance. Moreover, these results are consistent with those reported by Budagaga (2020), Ashraf and Zheng (2015), Al-Najjar (2009), Al-Malkawi (2007) and Fama and French (2001).

As for bank liquidity (CASH_R), while the results show that the coefficient of bank liquidity has a positive sign, it is not significant and therefore does not explain the banks' propensity to pay dividends (column 1) or the banks' dividend payout ratio (column 2). Consequently, $H 3 a$ and $H 3 b$ are not supported. These results suggest that banks with high levels of cash have a slight tendency to make cash dividend payments and to slightly increase their cash dividend payout ratio. Despite the weak evidence regarding the effect of bank liquidity on Palestinian banks' propensity to pay dividends and on their dividend payout ratios, these results are somewhat in line with dividend-signaling theory (Bhattacharya, 1979; Kalay, 1980; John \& Williams, 1983) that implies that companies with reasonable levels of cash are more likely to pay cash dividends and/or to raise their paid dividend ratios in order to signal to market that they have cash flow stability. 
As regards the fourth and last potential explanatory factor, the findings of the present study indicate that bank capital adequacy (E_TA) significantly and positively affects the banks' propensity to pay dividends $(\mathrm{H} 4 \mathrm{a})$ at the $1 \%$ level (column 1) and significantly and positively affects the banks' dividend payout ratio $(H 4 b)$ at the $10 \%$ level (column 2$)$ as expected. Consequently, $H 4 a$ and $H 4 b$ are supported. These results suggest that banks with high levels of capital adequacy (low leverage levels) are more likely to make cash dividend payments and/or to raise their cash dividend payout ratios. These results are in line with the regulatory pressure hypothesis in the context of banks' dividend policy, where the amount of dividends that a bank can disburse is subject to regulatory restriction such as the requirement to have a certain capital adequacy level (Baker et al., 2008). Therefore, when banks have high capital adequacy levels (low leverage levels) they have a greater ability to pay dividends. Moreover, these results are consistent with those of Budagaga (2020) and Ashraf and Zheng (2015).

Finally, it is important to note that for robustness purposes, all the continuous variables were winsorized at the $2.5 \%$ and $97.5 \%$ levels in order to eliminate outlier effects. Thereafter, the same analyses were performed again. Table 6 presents the Probit analysis of Model 1 and the OLS analysis of Model 2 in columns 3 and 4, respectively. The findings after winsorization of the data are consistent with the findings of the main analysis.

\subsection{General dominance analysis}

According to the above results, three out of the four predictors or independent variables (bank size, bank profitability and bank capital adequacy) have an impact on the dependent variables (propensity to pay dividends and dividend payout ratio) of Palestinian banks. To deepen understanding of the role of the predictors in the banks' dividend policy decisions, it is useful to determine the relative importance of the predictors (Budescu, 1993) by using general dominance analysis (Azen $\&$ Traxel, 2009). Therefore, the relative importance of the effective independent variables and their impact on the dependent variables in the multiple regression models was determined. As shown in Table 7, in the case of Model 1 in which Probit technique was used because the dependent variable was banks' propensity to pay dividends, bank size was found to be the most important independent variable, followed by bank profitability and bank capital adequacy. Similarly, the same relative order of importance was found for Model 2 in which the OLS technique was used because the dependent variable was the banks' dividend payout ratio.

Table 7

Dominance Statistics.

\begin{tabular}{lllllll}
\hline $\begin{array}{l}\text { Independent } \\
\text { Variables }\end{array}$ & \multicolumn{2}{l}{ Model (1) Probit Analysis } & & \multicolumn{2}{l}{ Model (2) OLS Analysis } \\
\cline { 2 - 6 } & $\begin{array}{l}\text { Dominance } \\
\text { statistics. }\end{array}$ & $\begin{array}{l}\text { Standardized } \\
\text { domin. stat. }\end{array}$ & Rank & $\begin{array}{l}\text { Dominance } \\
\text { statistics. }\end{array}$ & $\begin{array}{l}\text { Standardized } \\
\text { domin. stat. }\end{array}$ & Rank \\
\hline $\begin{array}{l}\text { Bank size } \\
\text { (LOG_TA) }\end{array}$ & 0.268 & 0.595 & $\mathbf{1}$ & 0.219 & 0.496 & $\mathbf{1}$ \\
$\begin{array}{l}\text { Bank } \\
\text { profitability } \\
\text { (ROAA) }\end{array}$ & 0.161 & 0.357 & $\mathbf{2}$ & 0.181 & 0.410 & $\mathbf{2}$ \\
$\begin{array}{l}\text { Bank capital } \\
\text { adequacy } \\
\text { (E_TA) }\end{array}$ & 0.021 & 0.047 & $\mathbf{3}$ & 0.041 & 0.094 & $\mathbf{3}$ \\
\hline
\end{tabular}

\section{Conclusion}

Unlike most dividend policy studies which have been conducted on non-financial companies, this study investigated the dividend policy determinants in banks. Specifically, the aims of this study were twofold. The first aim was to examine whether dividend theories that were principally developed for non-financial companies in developed institutional environments and extensively explored in such environments can explicate the dividend policies of banks in Palestine, an emerging market with a high level of uncertainty, i.e., a disturbed environment. The second aim was to determine the main factors that affect Palestinian banks' propensity to pay dividends and their dividend payout ratios. This study used two dependent variables to represent Palestinian banks' dividend policy. The first was the banks' propensity to pay dividends, which was represented by a dummy variable (DIV_D) and thus the Probit technique was used in the analysis. The second was the dividend payout ratio, which was represented by a continuous variable (DPOR) and thus the OLS technique was used in the analysis. The findings suggest that bank size, bank profitability and bank capital adequacy are the three key factors that affect Palestinian banks' propensity to pay dividends (Probit analysis) and their dividend payout ratios (OLS analysis). The other independent variable, liquidity has weak influence on bank's propensity to pay dividends and dividend payout ratios. The findings of this study are consistent with agency cost theory, which was found to be valid for Palestinian banks in respect of the effect of bank size (LOG_TA) on dividend policy, wherein large banks are more likely to make the decision to pay out cash dividends and/or to raise their cash dividend payout ratios in order to mitigate agency costs. The findings are also in line with dividend-signaling theory (Bhattacharya, 1979; Kalay, 1980; John \& Williams, 1983) in regard to the impact of bank profitability (ROAA), wherein banks with high levels of profits are more likely to decide to pay cash 
dividends decision and or to raise their cash dividends payout ratios in order to signal to the market including depositors. In other words, profitable banks have a greater ability to pay (raise) dividends as compared to unprofitable banks. Moreover, the regulatory pressure hypothesis regarding banks' dividend policy (Baker et al., 2008) is valid for Palestinian banks and the influence of bank capital adequacy (E_TA), wherein it was found that banks with high levels of capital adequacy (low leverage levels) are more likely to decide to make cash dividend payments and/or to raise their cash dividend payout ratios. Importantly, consistent results were produced after winsorizing the data at the $2.5 \%$ and $97.5 \%$ levels. Moreover, according to the results of the general dominance analysis, bank size was found to be most important independent variable followed by bank profitability and bank capital adequacy in positively influencing the dividend policy decisions of Palestinian banks. Overall, the agency cost, signaling and regulatory pressure theories, which were originally developed for and examined in non-financial companies in developed institutional environments, are valid for Palestinian banks that are working in a lessdeveloped environment and under high levels of risk and uncertainty.

Nevertheless, it should be noted that the findings of this study have some limitations. Firstly, a sample size of 60 observations is small to offer conclusive evidence. Also, the study was restricted to one type of financial company, namely banks. Therefore, future studies may wish to include other kinds of financial company (e.g., insurance companies). In addition, this study mainly examined the validity of the agency cost, signaling and regulatory pressure theories in relation to Palestinian banks. Therefore, future research may wish to consider other theories such as the transaction cost, bird-in-hand, tax-related effect, life cycle, catering theories to determine whether they are valid for the Palestinian financial and nonfinancial sectors. Finally, this study was only able to consider a limited number of variables as bank-related determinants because of data availability issues. Therefore, further studies may wish to explore the effects of address ownership structure and corporate governance on dividend policy.

\section{Policy Implications}

The dividend policymakers in Palestinian banks seem to use dividend-signaling policy to send positive signals to the market about the financial well-being of their respective banks. Therefore, the management of these banks should avoid the disbursement of random cash dividends that do not convey signals to the market including depositors and investors because doing so would lead to a reduction in the banks' market value. Furthermore, having a good understanding of the dividend behavior of Palestinian banks will enable national regulatory bodies to implement more effective regulations to protect stakeholders' interests. Finally, the findings of this study can assist banks' stakeholders to build their dividend predictions and investment plans accordingly.

\section{References}

Abreu, J. F., \& Gulamhussen, M. A. (2013). Dividend payouts: Evidence from US bank holding companies in the context of the financial crisis. Journal of corporate Finance, 22(1), 54-65.

Abusharbeh, M. (2020). The financial soundness of the Palestinian banking sector: an empirical analysis using the CAMEL system. Banks and Bank Systems, 15(1), 1-14.

Acharya, V. V., Gujral, I., Kulkarni, N., \& Hyun Song Shin. (2011). Dividends and bank capital in the financial crisis of 2007-2009 (No. w16896). In National Bureau of Economic Research Working Paper, 1.

Aivazian, V., Booth, L., \& Cleary, S. (2003). Do emerging market firms follow different dividend policies from US firms?. Journal of Financial research, 26(3), 371-387.

Al-Kayed, L. T. (2017). Dividend payout policy of Islamic vs conventional banks: case of Saudi Arabia. International Journal of Islamic and Middle Eastern Finance and Management, 10(1), 117-128.

Al-Malkawi, H.-A. N. (2007). Determinants of Corporate Dividend Policy in Jordan: An Application of the Tobit Model. Journal of Economic and Administrative Sciences, 23(2), 44-70.

Al-Malkawi, H.-A. N. (2008). Factors Influencing Corporate Dividend Decision: Evidence from Jordanian Panel Data. International Journal Of Business, 13(2), 1-21.

Al-Najjar, B. (2009). Dividend behaviour and smoothing new evidence from Jordanian panel data. Studies in Economics and Finance, 26(3), 182-197.

Ashraf, B. N., \& Zheng, C. (2015). Shareholder protection, creditor rights and bank dividend policies. China Finance Review International, 5(2), 161-186.

Azen, R., \& Traxel, N. (2009). Using Dominance Analysis to Determine Predictor Importance in Logistic Regression. Journal of Educational and Behavioral Statistics, 34(3), 319-347.

Baker, H. K., Dutta, S., \& Saadi, S. (2008). Impact of financial and multinational operations on manager perceptions of dividends. Global Finance Journal, 19(2), 171-186.

Baker, M., \& Wurgler, J. (2004a). A catering theory of dividends. The Journal of Finance, 59(3), 1125-1165.

Baker, M., \& Wurgler, J. (2004b). Appearing and disappearing dividends: the link to catering incentives. Journal of Financial Economics, 73(2), 271-288.

Barhamzaid, Z. A. A., Zhang, X.-Z., \& Alleyne, A. (2018). The Impact of Behavioral Factors and War on Decision Making under Political Conflict: Evidence from Palestine. Research Journal of Finance and Accounting, 9(16), 1-9.

Boţoc, C., \& Pirtea, M. (2014). Dividend payout-policy drivers: Evidence from emerging countries. Emerging Markets Finance and Trade, 50(1), 95-112. 
Budagaga, A. R. (2020). Determinants of banks' dividend payment decisions: evidence from MENA countries. International Journal of Islamic and Middle Eastern Finance and Management, 13(5), 847-871.

Budescu, D. V. (1993). Dominance analysis: A new approach to the problem of relative importance of predictors in multiple regression. Psychological Bulletin, 114(3), 542-551.

Calomiris, C. W., \& Nissim, D. (2014). Crisis-related shifts in the market valuation of banking activities. Journal of Financial Intermediation, 23(3), 400-435.

Chowdhury, R. H., Maung, M., \& Zhang, J. (2014). Information content of dividends: A case of an emerging financial market. Studies in Economics and Finance, 31(3), 272-290.

Dewasiri, N. J., Koralalage, W. B. Y., Azeez, A. A., Jayarathne, P. G. S. A., Kuruppuarachchi, D., \& Weerasinghe, V. A. (2019). Determinants of dividend policy: evidence from an emerging and developing market. Managerial Finance, 45(3), 413-429.

Fama, E. F., \& French, K. R. (2001). Disappearing dividends: Changing firm characteristics or lower propensity to pay? Journal of Financial Economics, 60(1), 3-43.

Forti, C., \& Schiozer, R. F. (2015). Bank dividends and signaling to information-sensitive depositors Cristiano. Journal of Banking \& Finance, 56(1), 1-17.

Gordon, M. J. (1963). Optimal Investment and Financing Policy. The Journal of Finance, 18(2), 264-272.

Gropp, R., \& Heider, F. (2010). The Determinants ofBank Capital Structure. Review of Finance, 14(4), $587-622$.

Gujarati, D. (2009). Basic econometrics. Tata McGraw-Hill Education.

Ho, H. (2003). Dividend Policies in Australia and Japan. International Advances in Economic Research, 9(1), 91-100.

Jensen, M. C. (1986). Agency Cost Of Free Cash Flow, Corporate Finance, and Takeovers. American Economic Review, $76(2), 323-329$

Jensen, M., \& Meckling, W. (1976). Theory of the firm: managerial behavior, agency costs and ownership structure. Journal of Financial Economics, 3(4), 305-360.

John, K., \& Williams, J. (1983). Dividends, Dilution, and Taxes: a Signalling Equilibrium. The Financial Review, 18(3), $51-51$.

Kalay, A. (1980). Signaling, Information Content, and the Reluctance to Cut Dividends. The Journal OfFinancial and Quantitative Analysis, 15(4), 19-21.

Kauko, K. (2012). Why is Equity Capital Expensive for Opaque Banks?, Bank of Finland Research Discussion Paper, 4.

Kullab, Y., \& Yan, C. (2018). Soundness of Palestinian Banks- 10 Years Based Analysis. IOSR Journal of Business and Management, 20(8), 16-29.

Kumar, B. R., \& Waheed, \& K. A. (2015). Determinants of Dividend Policy: Evidence from GCC Market. Accounting and Finance Research, 4(1), 17-29.

Kuo, J.-M., Philip, D., \& Zhang, Q. (2013). What drives the disappearing dividends phenomenon? Journal of Banking \& Finance, 37(1), 3499-3514.

Lepetit, L., Meslier, C., Strobel, F., \& Wardhana, L. (2018). Bank dividends, agency costs and shareholder and creditor rights. International Review of Financial Analysis, 56(1), 93-111.

Lintner, J. (1964). Optimal Dividends and Corporate Growth Under Uncertainty. The Quarterly Journal of Economics, $78(1), 49-95$

Miller, M. H., \& Modigliani, F. (1961). Dividend Policy, Growth, and the Valuation of Shares. The Journal of Business, 34(4), 411-433.

Myers, S. C. (1984). The Capital Structure Puzzle. The Journal of Finance, 39(3), 574-592.

Myers, S. C., \& Majiuf, N. S. (1984). Corporate financing and investment decisions when firms have information the investors do not have. Journal of Financial Economics, 13(2), 187-221.

Petersen, M. A. (2009). Estimating Standard Errors in Finance Panel Data Sets: Comparing Approaches. The Review of Financial Studies, 22(1), 435-480.

Rodrigues, R., Felício, J. A., \& Verga Matos, P. (2020). Corporate Governance and Dividend Policy in the Presence of Controlling Shareholders. Journal of Risk and Financial Management, 13(8), 1-15.

Séverin, E., \& du Jardin, P. (2011). Dividend policy. Bankers, Markets \& Investors, 115(1), 37-54.

Strong, N. (1998). Discussion of does the prcking order hypothesis explain the dividend payout ratios of firms in the UK. Journal of Business Finance \& Accounting, 25(9), 1157-1161.

Warganegara, D. L., Indrawati, T., Steelyana, E., Warganegara, D. S., \& Loo, M. K. L. (2020). Tobit Regression Analysis on Factors Influencing Dividend Policy of Indonesian Manufacturing Firms. Pertanika Social Sciences \& Humanities, $28(1), 243-252$.

Yoshikawa, T. and Rasheed, A. A. (2010) 'Family control and ownership monitoring in family-controlled firms in Japan', Journal of Management Studies, 47(2), 274-295. 
(C) 2022 by the authors; licensee Growing Science, Canada. This is an open access article distributed under the terms and conditions of the Creative Commons Attribution (CC-BY) license (http://creativecommons.org/licenses/by/4.0/). 